\title{
Antifungal Mechanism of Dipicolinic Acid and Its Efficacy for the Biocontrol of Pear Valsa Canker
}

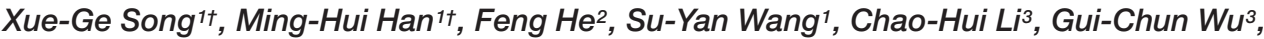

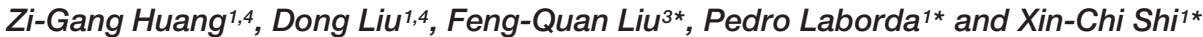 \\ ${ }^{1}$ School of Life Sciences, Nantong University, Nantong, China, ${ }^{2}$ College of Life Science, Anhui Normal University, Wuhu, \\ China, ${ }^{3}$ Jiangsu Key Laboratory for Food Quality and Safety-State Key Laboratory Cultivation Base of Ministry of Science \\ and Technology, Institute of Plant Protection, Jiangsu Academy of Agricultural Sciences, Nanining, China, ${ }^{4}$ Jiangsu Key \\ Laboratory of Neuroregeneration, Co-innovation Center of Neuroregeneration, Nantong University, Nantong, China
}

\section{OPEN ACCESS}

Edited by:

Brigitte Mauch-Mani, Université de Neuchâtel, Switzerland

Reviewed by: Lili Huang,

Northwest A\&F University, China

Caixia Wang

Qingdao Agricultural University, China

*Correspondence: Xin-Chi Shi shxch0301@ntu.edu.cn

Pedro Laborda pedro@ntu.edu.cn

Feng-Quan Liu fqliu20011@sina.com

${ }^{\dagger}$ These authors have contributed equally to this work

Specialty section: This article was submitted to Plant Microbe Interactions,

a section of the journal Frontiers in Microbiology

Received: 02 February 2020 Accepted: 21 April 2020 Published: 20 May 2020

Citation:

Song X-G, Han M-H, He F, Wang S-Y, Li C-H, WU G-C, Huang Z-G, Liu D, Liu F-Q, Laborda P

and Shi X-C (2020) Antifungal Mechanism of Dipicolinic Acid and Its Efficacy for the Biocontrol of Pear Valsa Canker.

Front. Microbiol. 11:958. doi: 10.3389/fmicb.2020.00958
Valsa pyri is a fatal canker pathogen that causes significant reduction of crop yield in pear orchards. $V$. pyri invades the trunk phloem, and is difficult to control by chemical treatment. In this work, it was found for the first time that Bacillus subtilis-produced dipicolinic acid (DPA) exhibits antifungal activity against different canker pathogens, including Alteraria alternata, Botryosphaeria dothidea, Rhizoctonia solani, and V. pyri. Growth inhibition of $V$. pyri was observed at less than $5 \mathrm{mM}$ concentration $(\mathrm{pH}=5.6)$. DPA showed the highest antifungal activity at acidic $\mathrm{pH}$ values and in the presence of bivalent metals, such as zinc(II), cobalt(II), and copper(II). Measurement of mRNA expression levels and scanning electron microscope (SEM) observations revealed that DPA causes $V$. pyri apoptosis via inhibition of chitin biosynthesis and subsequent cell lysis. Interestingly, DPA showed high stability in the pear bark and was able to cross the pear tree bark into the phloem, protecting the internal phases of the pear trunk. In preventive applications, DPA reduced the canker symptoms of $V$. pyri on Cuigan pear trees by $90 \%$. Taken together, an efficient strategy for the management of $V$. pyricaused canker disease was developed using a novel antifungal agent, DPA, with strong antifungal activity and particular diffusion properties.

Keywords: Valsa canker, dipicolinic acid, fungal apoptosis, Bacillus subtilis, biological control

\section{INTRODUCTION}

Pears are the third most consumed fruit after apples and grapes. Pear global production reached 24.1 million tons in 2017, with major production areas in China, Italy, the USA, Argentina and Spain (Food and Agriculture Organization of the United Nations [FAO], 2017). Pear trees are highly susceptible to a wide range of devastating pathogens. Among pear tree diseases,

\footnotetext{
Abbreviations: ACAT, acyl-CoA sterol acyltransferase; B. subtilis, Bacillus subtilis; CHS, chitin synthase gene; CRZ, $\mathrm{Ca}^{2+} /$ calcineurin-dependent transcription factor; DAPI, 4',6-diamino-2-phenylindole; DHCR, 7-dehydrocholesterol reductase; DPA, dipicolinic acid; ESI, electrospray ionization; FAO, Food and Agriculture Organization of the United Nations; GS, glucan synthase gene; h, hours; HMGCR, 3-hydroxy-3-methylglutamyl-CoA reductase; HPLC, high-performance liquid chromatography; LB, lysogeny broth; min, minutes; mRNA, messenger RNA; MS, mass spectrometry; ns, no significance; MW, molecular weight; pABA, $p$-aminobenzoic acid; PDA, potato dextrose agar; $q$ PCR, real-time polymerase chain reaction; $R C R$, congo red resistance gene; rpm, revolutions per minute; r.t., room temperature; $S M T$, sterol C24-methyl transferase gene; YEPD, yeast extract peptone dextrose; V. pyri, Valsa mali var. pyri.
} 
canker diseases are common, widespread and destructive, and result in significant economic loss and significant crop losses (Zhai et al., 2014; Chen et al., 2016). However, only few management strategies were reported until the date. In this sense, some chemical fungicides, such as thiophanate-methyl and copper (II)-humic acid complex, have been applied for the control of pear cankers in China, whereas Lysobacter enzymogenes-produced heat stable antifungal factor (HSAF) could reduce the symptoms of Valsa canker by $81.3 \%$ (Cheng et al., 2017). Acibenzolar-S-methyl was shown to induce systemic acquired resistance in susceptible field-grown pear trees to fire blight (Johnson and Temple, 2017).

Valsa mali var. pyri, also known as $V$. pyri, is an aggressive canker pathogen that causes pear and apple canker disease on many continents, including Asia. This fungus invades host tissue wounded by injury in the bark (He et al., 2016; Kange et al., 2020). The pathogen can invade the phloem, resulting in vascular tissue necrosis, which can result in the death of the pear tree (Yin et al., 2015; Li et al., 2016). The necrotrophic action has been attributed to secretion of pectinases and other degrading enzymes that promote the infection and colonization of the host trunk ( $\mathrm{Li}$ et al., 2015; Yin et al., 2015). The disease is difficult to control with chemical treatments since most active compounds are not able to protect the internal phases of the tree trunk, allowing the pathogen to advance. For this reason, the most common way to contain this disease is to destroy the infected plants.

Bacillus species have been shown to be a promising source of metabolites with antifungal activities (Caulier et al., 2019). Among Bacillus species, B. subtilis has been thoroughly explored as biocontrol agent for the management of many plant diseases including Valsa canker (Santoyo et al., 2012; Liu et al., 2015; Siahmoshteh et al., 2018). B. subtilis E1R-J-secreted protein EP2 showed antifungal activity against apple Valsa canker (Wang et al., 2016). An antifungal protein isolated from B. subtilis XB1 inhibited Monilia fructicola growth (Ren et al., 2019; Zhou et al., 2019). B. subtilis C232-secreted lipopeptides inhibited microsclerotia formation in Verticillium dahliae (Yu et al., 2018). B. subtilis $7 \mathrm{PJ}-16$ was used as biocontrol agent of mulberry fruit sclerotiniose (Xu et al., 2019). In this work, a new antifungal compound, dipicolinic acid (DPA), was isolated from B. subtilis 168 secretions, and showed strong antifungal activity against four pear canker pathogens. DPA was demonstrated to inhibit the biosynthesis of chitin in $V$. pyri, producing cell wall damage and, subsequently, the fungal death. Interestingly, DPA showed high stability in the pear bark, and was able to diffuse into the phloem, protecting the internal phases of the trunk. Preventive applications of DPA inhibited in vivo V. pyri growth by $90 \%$.

\section{MATERIALS AND METHODS}

\section{General Information and Strains}

All reagents and chemicals were used as received from commercial suppliers without further purification or modification. DPA was purchased from Macklin (China), and used in the antifungal mechanism studies. Mass spectrometry analyses were carried out in a QTRAP 5500 Linear Ion Trap Quadrupole MS/MS Mass Spectrometer (AB Sciex Instruments, United States). Fungal strains, including A. alternata, B. dothidea, $R$. solani, and $V$. pyri, were grown on potato dextrose agar medium (PDA). PDA medium was prepared by boiling $200 \mathrm{~g}$ of potatoes in $1 \mathrm{~L}$ of water for $30 \mathrm{~min}$. Then, $20 \mathrm{~g}$ dextrose was added $(\mathrm{pH}=5.6)$.

\section{Data Analysis}

The statistical analyses were performed using SPSS (Statistical Package, Version 20.0). The variables were subjected to student's $t$-test and were tested for significance at $P<0.05\left(^{*}\right), P<0.01$ $\left.{ }^{* *}\right), P<0.001\left(^{* * *}\right)$, and $P<0.0001\left(^{* * * *}\right)$ levels (ns $=$ no significance). The standard deviation, which was calculated using Microsoft Excel 2010, was used to quantify the dispersion.

\section{Media and Growth Conditions for}

\section{B. subtilis}

B. subtilis 168 strain was maintained on lysogeny broth (LB; $5 \mathrm{~g}$ yeast extract, $10 \mathrm{~g}$ tryptone, and $10 \mathrm{~g}$ sodium chloride at $\mathrm{pH}$ 7.0-7.2 in $1 \mathrm{~L}$ of distilled water) agar plate at $37^{\circ} \mathrm{C}$. Seed cultures were grown at $37^{\circ} \mathrm{C}$ and $200 \mathrm{rpm}$ in $250 \mathrm{~mL}$ Erlenmeyer flasks containing $50 \mathrm{~mL} \mathrm{LB}$ medium until $\mathrm{OD}_{600}=2.0$. After centrifugation of $10 \mathrm{~mL}$ of seed culture at $8,000 \times g$ and $4^{\circ} \mathrm{C}$ for $10 \mathrm{~min}$, the collected cells were added into $100 \mathrm{~mL} \mathrm{LB}$ medium for the preparation of the fermentation cultures. The fermentation cultures were shaken in a $250 \mathrm{~mL}$ Erlenmeyer flask at $37^{\circ} \mathrm{C}$ and $200 \mathrm{rpm}$ for $72 \mathrm{~h}$.

\section{Isolation and Identification of DPA}

Five milliliters of $B$. subtilis 168 fermentation culture were centrifuged for $6 \mathrm{~min}$ at $10,000 \times g$ and $4^{\circ} \mathrm{C}$. Then, the filtered supernatant was studied by high-performance liquid chromatography (HPLC; Agilent 1200 series, Hewlett-Packard, United States) with an ultraviolet-visible light absorbance detector, using a high-performance carbohydrate column $(250 \times 4.6 \mathrm{~mm}$, Waters, Japan $)$ at $32^{\circ} \mathrm{C}$, a mixture of acetonitrile/water $1: 1(\mathrm{pH}=3.4)$ as mobile phase at a constant flow rate of $0.4 \mathrm{~mL} / \mathrm{min}$ (injection volume: $100 \mu \mathrm{L}$ ) for $15 \mathrm{~min}$.

All the peaks in the chromatogram were collected by analytical scale HPLC. The collected peaks from $5 \mathrm{~mL}$ fermentation culture were evaporated using a freeze-drier, and re-dissolved in $100 \mu \mathrm{L}$ water. The antifungal activity of the peaks was tested using $V$. pyri. To achieve this goal, the fungal pathogen was located on the center of the Petri dish containing PDA medium. Then, a $3 \mathrm{~mm}$ diameter hole was performed in the solid growth medium, and $30 \mu \mathrm{L}$ of the collected peaks was poured in it. The plate was then incubated during $48 \mathrm{~h}$ at $28^{\circ} \mathrm{C}$. The antifungal activity was detected by measurement of the diameter of the inhibition zone.

Among the collected peaks, only one peak at $10.1 \mathrm{~min}$ showed antifungal activity. The corresponding compound was isolated by analytical scale HPLC, and identified as DPA by mass chromatography (MS (ESI): calcd. for $\mathrm{C}_{7} \mathrm{H}_{4} \mathrm{NO}_{4}[\mathrm{M}-$ $\mathrm{H}]^{-}$166.0140, found 166.0). The concentration of DPA in the fermentation culture was calculated according to the peak area. A standard curve was established from 0 to $2 \mathrm{mM}$ DPA. The 
fermentation cultures were repeated 3 times to calculate the standard deviation.

\section{Antifungal Activity Assay}

The antifungal activity of DPA was tested using the following plant pathogens: A. alternata, B. dothidea, R. solani, and V. pyri. Commercial DPA was used in these experiments. The antifungal screening was carried out using a similar protocol previously reported by our research group (Laborda et al., 2018). Briefly, the fungal pathogen was placed in the center of a Petri dish containing PDA medium $(\mathrm{pH}=5.6)$ and DPA at 3,5 , and $10 \mathrm{mM}$, respectively. The antifungal activity was calculated by measurement of the diameter of the mycelial growth. The control treatments were performed in the absence of DPA. The dishes were incubated at $28^{\circ} \mathrm{C}$ for 3 days for A. alternata, $R$. solani, and $V$. pyri; and 7 days for $B$. dothidea. Three replicates were performed for each treatment.

\section{Conidium Germination Assay}

V. pyri wild-type strain Vp297 was isolated from diseased pear trees and validated as previously reported by our research group (He et al., 2016). The isolate was preserved as a glycerol stock (20\%) at $-80^{\circ} \mathrm{C}$ in the Plant Bacteria and Biocontrol Laboratory, Institute of Plant Protection, Jiangsu Academy of Agricultural Sciences. To carry out the conidium germination assay, V. pyri was grown on $\mathrm{PDA}$ medium at $28^{\circ} \mathrm{C}$ for 5 days, and the mycelia were divided into $3 \mathrm{~mm}$ diameter plugs. Then, conidial production was induced by culturing three plugs of $V$. pyri in $40 \mathrm{~mL}$ barley-honey-tryptone medium at $28^{\circ} \mathrm{C}$ and $200 \mathrm{rpm}$ for $24 \mathrm{~h}$. Barley-honey-tryptone medium was prepared by heating $600 \mathrm{mg}$ honey, $100 \mathrm{mg}$ barley and $200 \mathrm{mg}$ tryptone in $40 \mathrm{~mL}$ water at $121^{\circ} \mathrm{C}$ for $1 \mathrm{~h}$ (Zhao et al., 2012). Freshly harvested conidia were suspended in germination solutions $\left(1 \times 10^{6}\right.$ conidia $\left./ \mathrm{mL}\right)$, and the germination was assayed after incubation at $28^{\circ} \mathrm{C}$ and $200 \mathrm{rpm}$ for $24 \mathrm{~h}$. The germination solutions consisted of $100 \mu \mathrm{L}$ YEPD medium ( $0.15 \mathrm{~g}$ yeast extract, $0.5 \mathrm{~g}$ tryptone, $1 \mathrm{~g}$ glucose, $\mathrm{pH}=5$, in $50 \mathrm{~mL}$ water) and $100 \mu \mathrm{L}$ water with $3 \mathrm{mM} \mathrm{DPA}$ $(\mathrm{pH}=5)$. Two hundred microliters YEPD/water $1: 1$, in the absence of DPA, was used as the control treatment. Fungal growth was detected using either a Leica DM2500 microscope at $\times 4$, $\times 10, \times 20$, and $\times 40$ magnifications, a Nikon A1R HD25 inverted microscope at $\times 4, \times 10, \times 20$, and $\times 40$ magnifications, or a SEM Gemini 300 instrument.

To prove whether DPA could cause cell death, the conidia were prepared as mentioned above. Then, the conidia were shaken at $28^{\circ} \mathrm{C}$ and $200 \mathrm{rpm}$ for $24 \mathrm{~h}$ using a $5 \mathrm{mM}$ DPA YEPD/water 1:1 solution $(200 \mu \mathrm{L}, \mathrm{pH}=5)$. After centrifugation of the cells, the upper phase was discarded and the cells were washed with $100 \mu \mathrm{L}$ YEPD medium to remove the traces of DPA. Finally, the cells were suspended in $200 \mu \mathrm{L}$ YEPD/water 1:1. The resulting suspension was stirred at $28^{\circ} \mathrm{C}$ and $200 \mathrm{rpm}$ for $24 \mathrm{~h}$, and the fungal growth was analyzed using a Leica DM2500 microscope.

The effect of $\mathrm{pH}$ and metals on the conidia germination was detected using $1 \mathrm{mM}$ DPA. The effect of the $\mathrm{pH}$ was calculated at $\mathrm{pH}$ values $3,4,5,6,7,8$ and 9. The experiments were performed in $200 \mu \mathrm{L} \mathrm{YEPD/water} \mathrm{1:1.} \mathrm{The} \mathrm{effect} \mathrm{of} \mathrm{iron(II),}$ nickel(II), zinc(II), cobalt(II), and copper(II) on the conidia germination was examined by adding $1 \mathrm{mM}$ of the corresponding metal chloride into the germination medium at $\mathrm{pH}=5$. The germination was analyzed with a Leica DM2500 microscope. The antifungal activity was calculated according to the number of conidia per $\mu \mathrm{L}$.

\section{Fluorescent Live-Cell Imaging}

To collect the images, the conidia were prepared as mentioned in the "Conidium Germination Assay" section. Freshly harvested conidia were suspended in a YEPD/water 1:1 solution $(200 \mu \mathrm{L})$ containing 3 or $5 \mathrm{mM}$ DPA $\left(1 \times 10^{6}\right.$ conidia/mL, $\left.\mathrm{pH}=5\right)$. After shaking at $28^{\circ} \mathrm{C}$ and $200 \mathrm{rpm}$ for 0,24 or $72 \mathrm{~h}, 10 \mu \mathrm{L}$ of the germination suspension was stained with $10 \mu \mathrm{L} 4^{\prime}, 6$ diamino-2-phenylindole (DAPI, $10 \mu \mathrm{g} / \mathrm{mL}$ solution, Solarbio). The stained samples were observed with an Olympus BX51 fluorescence microscope.

\section{Detection of mRNA Levels in V. pyri After Treatment With DPA}

After preparation of $V$. pyri conidia following the conditions described in the "Conidium Germination Assay" section, freshly harvested conidia $\left(5 \times 10^{6}\right.$ cells) were suspended in a solution containing $0.5 \mathrm{~mL}$ YEPD and $0.5 \mathrm{~mL}$ water $(\mathrm{pH}=5)$. The resulting suspension was shake at $28^{\circ} \mathrm{C}$ and $200 \mathrm{rpm}$ for $24 \mathrm{~h}$. The treatment experiment was done using $3 \mathrm{mM}$ DPA, whereas the control experiment was performed in the absence of DPA. The conidial suspension was centrifuged at $4^{\circ} \mathrm{C}$ and $10,000 \times g$ for $6 \mathrm{~min}$, and the cells were harvested and washed with $200 \mu \mathrm{L}$ water. Total RNA was extracted using TRIzol reagent (Ambion, United States). The residual DNA was removed and the firststrand cDNA was synthesized in one pot using the Transcript All-in-One First-Strand DNA Synthesis SuperMix for qPCR (One Step gDNA Removal) Kit (Tsingke, China). Quantitative realtime PCR was performed using a set of 2 PCR primers with SYBR Green I Real Time PCR (Solarbio, United States). The PCR analysis was carried out using a 7500 Real time PCR system (Applied Biosystems, United States). The mRNA levels of ergosterol biosynthesis genes VpDHCR (Vp_08088), VpHMGCR (Vp_03215), VpACAT (Vp_07270), and VpSMT (Vp_08294), glucan biosynthesis genes VpGS1 (Vp_08744) and VpGS2 (Vp_00561), and chitin biosynthesis genes VpCHS2, VpCHS6, $V p C R Z 1, V p R C R 1$, and $V p R C R 2$, were examined. Primers were designed according to the gene sequences using Primer Premier 5.0 (Supplementary Table S1). The DNA sequences of all studied genes were previously reported by our research group (He et al., 2016). In all cases, VpActin was used as a reference gene (He et al., 2018), and the relative gene expression was calculated by the $2^{-\Delta}$ $\Delta c t$ method.

\section{Determination of Chitin Content}

$V$. pyri conidia were prepared following the conditions described in the "Conidium Germination Assay" section. Freshly harvested conidia were suspended in a YEDP/water 1:1 solution $(1 \mathrm{~mL})$ with $3 \mathrm{mM}$ DPA $(\mathrm{pH}=5)$. The control experiment was performed in the absence of DPA. The resulting solution $\left(1 \times 10^{6}\right.$ conidia $/ \mathrm{mL}$ ) was shake at $28^{\circ} \mathrm{C}$ and $200 \mathrm{rpm}$. The content of 
chitin was detected at 0, 1, 2 and 3 days (Kapteyn et al., 2000). Briefly, extracted cell walls were hydrolyzed in $1 \mathrm{~mL} 6 \mathrm{M} \mathrm{HCl}$ at $100^{\circ} \mathrm{C}$ for $17 \mathrm{~h}$. After evaporation of the solvent using a freeze-drier, the samples were dissolved in $1 \mathrm{~mL}$ water. A 0.75 $\mathrm{M} \mathrm{Na} \mathrm{CO}_{3}$ solution $(100 \mu \mathrm{L})$ was added to $100 \mu \mathrm{L}$ sample. The mixture was incubated at $100^{\circ} \mathrm{C}$ for $20 \mathrm{~min}$. Then, $95 \%$ ethanol $(0.7 \mathrm{~mL})$ and solution A $(100 \mu \mathrm{L}$; solution A: $1.6 \mathrm{~g}$ p-dimethylaminobenzaldehyde in $30 \mathrm{~mL}$ concentrated $\mathrm{HCl}$ and $30 \mathrm{~mL}$ ethanol) were added. The absorbance at $420 \mathrm{~nm}$ was measured and compared with the standard curve from 0.1 to $20 \mathrm{mg} / \mathrm{mL}$ glucosamine. The experiments were repeated 3 times.

\section{Detection of DPA in Pear Trunk}

Two-year Cuigan pear trees in fields were covered with plastics to avoid the direct effect of the environment. Branches of approximately $2 \mathrm{~cm}$ diameter were selected, and sprayed with a $12 \mathrm{mM}$ aqueous DPA solution $(300 \mathrm{~mL})$. To control the presence of DPA in the branches, one piece of pear trunk, $1 \mathrm{~cm}^{2}$ containing bark and phloem, was extracted from each branch with a knife. Each extracted piece was carefully divided into bark and phloem. The sample collections were carried out after $0,1,3,5,10,15$, and 20 days. Five pear branches were used for each time point, and 2 pieces of trunk were extracted from each branch (10 samples were collected for each time point). The trunk pieces were freeze-dried in Eppendorf tubes. Then, water $(200 \mu \mathrm{L})$ was added to each tube, and the tube was stirred at $500 \mathrm{rpm}$ for $15 \mathrm{~min}$. The presence of DPA in the aqueous solutions was analyzed using HPLC. HPLC conditions: reversedphase HPLC (Agilent 1200 Series, United States) at $270 \mathrm{~nm}$ using an Eclipse XDB-C18 column $(250 \times 4.6 \mathrm{~mm}$, Agilent $)$. A constant flow, $0.3 \mathrm{~mL} / \mathrm{min}, 0.03 \mathrm{M} \mathrm{H}_{2} \mathrm{SO}_{4}$ aqueous solution was used (column temperature: $60^{\circ} \mathrm{C}$; injection volume: $50 \mu \mathrm{L}$ ). DPA appeared at $6.7 \mathrm{~min}$ retention time using the aforementioned conditions. The concentration of DPA in the solutions was calculated according to the peak area using a standard curve from 0 to $10 \mathrm{mM}$ DPA.

\section{Curative and Preventive Efficacies of DPA for the Management of Valsa Canker}

To evaluate the preventive and curative efficacies of DPA, V. pyri conidia was produced following the conditions described in the "Conidium Germination Assay" section. For the preventive assay, $2 \mathrm{~mm}$ diameter holes were dug on branches of 2-year Cuigan pear trees. Then, a DPA aqueous solution $(12 \mathrm{mM}, 300 \mathrm{~mL}, \mathrm{pH}=5)$ was sprayed on 6 branches, whereas water $(300 \mathrm{~mL}, \mathrm{pH}=5)$ was sprayed on another 6 branches as a control treatment. After $2 \mathrm{~h}$, $10 \mu \mathrm{L}$ conidial suspension $\left(1 \times 10^{9}\right.$ conidia/mL $)$ was injected into each hole. Sixty inoculation sites were used in the study (30 inoculation sites for the treatment group, and 30 inoculation sites for the control group). Five inoculation points were carried out in each branch. After 7 days, the preventive efficacy was measured according to the lesion length. For the curative assay, sixty 2-mm-diameter holes were dug on the branches of 2-year Cuigan pear trees (12 branches were used with 5 holes in each one), and $10 \mu \mathrm{L}$ conidial suspension $\left(1 \times 10^{9}\right.$ conidia/mL) was injected into each hole. After $48 \mathrm{~h}$, a DPA aqueous solution
(12 mM, $300 \mathrm{~mL}, \mathrm{pH}=5$ ) was sprayed on 6 branches, whereas water $(300 \mathrm{~mL}, \mathrm{pH}=5)$ was sprayed on the other 6 branches as a control experiment. After 6 days, the curative efficacy was measured according to the lesion length. Pear tree branches of approximately $2 \mathrm{~cm}$ diameter were used in these experiments. $V$. pyri was successfully inoculated in all the inoculation sites, and the symptoms were easily observed after removing the bark with a knife. All results were used to calculate the average lesion length and deviation.

\section{RESULTS}

\section{Antifungal DPA Was Identified in B. subtilis 168 Secretions}

An antifungal metabolite was detected by HPLC at $10.1 \mathrm{~min}$ retention time in the secretions of wild-type B. subtilis 168 (Figure 1A). After purification of the active compound by HPLC, it was analyzed by mass spectrometry. MS analysis in negative mode revealed a main $\mathrm{m} / \mathrm{z}$ peak at 166.0 (Figure 1B), which is consistent with the expected molecular weight of a pyridine dicarboxylic acid structure, $[\mathrm{M}-\mathrm{H}]^{-}=166.0140$. MS/MS-analysis of this $\mathrm{m} / \mathrm{z}$ peak revealed ions at 121.9 and 78.0 (Figure 1C), demonstrating the presence of a pyridine dicarboxylic acid. Two different metabolites based on pyridine dicarboxylic acid structures, pyridine-2,3-dicarboxylic acid and DPA, are common metabolites in Bacillus secretions. It must be noted that DPA contains the carboxylic acid groups at positions 2 and 6 of the pyridine ring. In order to discern between both possible structures, pyridine-2,3-dicarboxylic acid and DPA were purchased from commercial suppliers and studied by HPLC. Pyridine-2,3-dicarboxylic acid appeared at $13.2 \mathrm{~min}$ retention time in the HPLC spectrum (Supplementary Figure S1), whereas the retention time of DPA was in well agreement with the observed antifungal metabolite. The concentration of DPA in the secretions of $B$. subtilis 168 was $0.24 \pm 0.01 \mathrm{mM}$ after $72 \mathrm{~h}$ cultivation in LB medium.

\section{DPA Caused the Apoptosis of $\boldsymbol{V}$. pyri}

The inhibitory activity of DPA was measured according to the mycelial growth of the fungal pathogens on PDA medium at $\mathrm{pH}=5.6$ (Figures 2A,B). DPA was able to block completely the growth of the $V$. pyri at $5 \mathrm{mM}$ concentration, whereas the complete inhibition of $B$. dothidea and A. alternata was detected at $10 \mathrm{mM}$ DPA (Supplementary Figure S2). The growth of R. solani was only inhibited by $70 \%$ at $10 \mathrm{mM} \mathrm{DPA}$.

The obtained results encouraged us to study the antifungal properties of DPA using V. pyri conidia. V. pyri conidia could not grow after treatment with $5 \mathrm{mM} \mathrm{DPA}$ for $24 \mathrm{~h}$ at $\mathrm{pH}=5$, indicating that DPA is able to cause irreversible effects on the fungi and to produce the cell death. Observations using microscope revealed for the first time that $V$. pyri forms mainly $4 \mu \mathrm{m}$ long dicellular conidia, which showed a "banana-like" shape (Figure 3A). It must be noted that tetracellular, tricellular and unicellular conidia were also detected in low proportion. Although DAPI commonly allows the observation of the fungal nuclei, V. pyri nuclei were not observed. However, the cell wall 

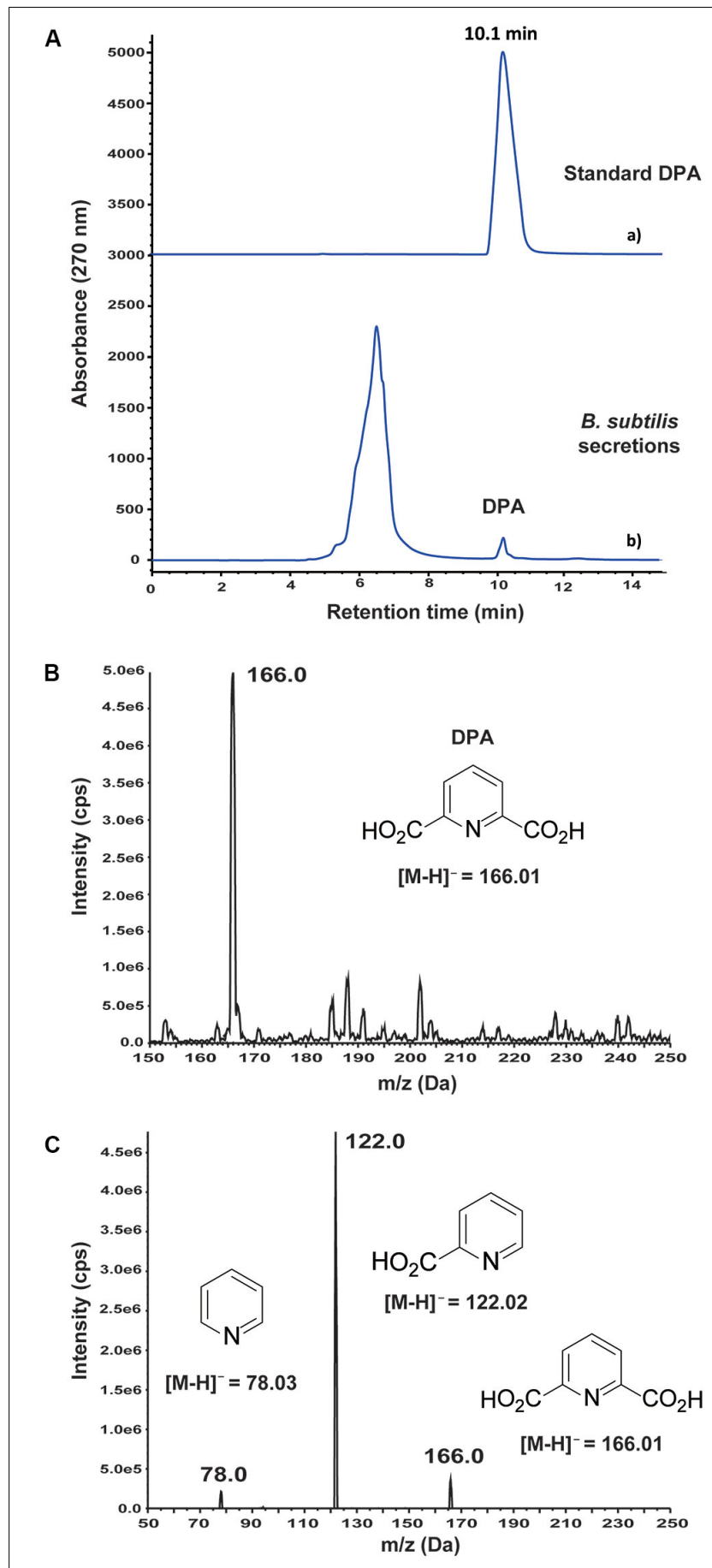

FIGURE 1 | Detection and identification of dipicolinic acid (DPA) in the secretions of wild-type Bacillus subtilis 168. (A) (a) Standard DPA; (b) HPLC-based study of $B$. subtilis 168 secreted metabolites. DPA was detected at $0.24 \pm 0.01 \mathrm{mM}$ concentration after growing $B$. subtilis 168 for $72 \mathrm{~h}$ in LB medium. (B) MS analysis of $B$. subtilis 168-secreted DPA. (C) MS/MS analysis of the $\mathrm{m} / \mathrm{z}$ peak at 166.0 Da.

and septa separations of $V$. pyri were clearly recognized after the DAPI stain (Supplementary Figure S3). In favorable conditions for $72 \mathrm{~h}, \mathrm{~V}$. pyri conidia germinated and formed multicellular structures. However, the treatment of $V$. pyri conidia with $3 \mathrm{mM}$ DPA reduced the number of conidia, suggesting that DPA is producing the cell lysis. It was observed that the treatment of $V$. pyri conidia with $5 \mathrm{mM}$ DPA for $72 \mathrm{~h}$ resulted in no observable cells after DAPI stain. Although the presence of $3 \mathrm{mM}$ DPA reduced the number of conidia, some conidia could germinate and form small multicellular structures.

The formation of small amounts of $V$. pyri conidia has been traditionally achieved by growing the fungi on PDA medium. However, the methodology reported by Zhao et al. (2012) for the production of $V$. ceratosperma conidia based on the incubation of the fungi with barley and honey was used in this occasion, and allowed the production of large amounts of $V$. pyri conidia.

$V$. pyri conidia could grow at different $\mathrm{pH}$ values, from 3 to 9, without relevant changes in growth or number of conidia (Figure 2C). It was found that the antifungal activity of DPA strongly depended on the $\mathrm{pH}$, obtaining the highest antifungal activities at acid $\mathrm{pH}$ values. In this sense, the number of conidia decreased by $79 \%$ at $\mathrm{pH}=3$ in the presence of $1 \mathrm{mM}$ DPA (Supplementary Figure S4), whereas the number of conidia was 52 and $38 \%$ lower when using $\mathrm{pH} 4$ and 5, respectively. No antifungal effect was detected with $1 \mathrm{mM}$ DPA at $\mathrm{pH}$ higher than 5.

DPA has been reported to be able to link to metals forming metallic complexes (Abdolmaleki et al., 2018). Here, the antifungal activity of $1 \mathrm{mM}$ DPA in the presence of different metals, including iron(II), nickel(II), zinc(II), cobalt(II) and copper(II), was studied using $V$. pyri conidia at $\mathrm{pH}=5$ (Figure 2D). The obtained results indicated that zinc(II), cobalt(II) and copper(II) at $1 \mathrm{mM}$ concentration can enhance the antifungal activity of DPA. The highest antifungal activity was detected in the presence of copper(II), which reduced the number of conidia by $54 \%$, whereas the number of conidia was reduced by only $35 \%$ in the absence of metals. On the other hand, no significant changes in the antifungal activity were observed when using iron(II) and nickel(II).

\section{DPA Inhibits Chitin Biosynthesis in V. pyri}

In order to clarify the antifungal mechanism, DPA-treated $V$. pyri conidia was studied using SEM and inverted microscope (Figure 3B and Supplementary Figure S5). It was found that the cells in the absence of DPA showed a round morphology. In contrast, the treatment with $5 \mathrm{mM}$ DPA for $24 \mathrm{~h}$ produced holes in the fungal membrane, causing the apoptosis. The partial degradation of the cell wall was detected in some occasions, whereas the complete degradation of the cell wall integrity was found in other conidia. This last option resulted in the appearance of an amorphous residue, which was easily observed using SEM and inverted microscope. These results suggested that DPA is causing the distortion of the cell wall integrity and, thus, producing the cell lysis. Three different kinds of antifungal agents based on the alteration of the cell wall integrity were reported: ergosterol, glucan and chitin biosynthesis inhibitors (Sharon et al., 2009). In order to discern between the 3 possibilities, the mRNA expression levels of relevant genes involved in the 3 processes were studied in the presence of $3 \mathrm{mM}$ DPA. Ergosterol biosynthetic pathway involves VpDHCR, VpHMGCR, VpACAT, 


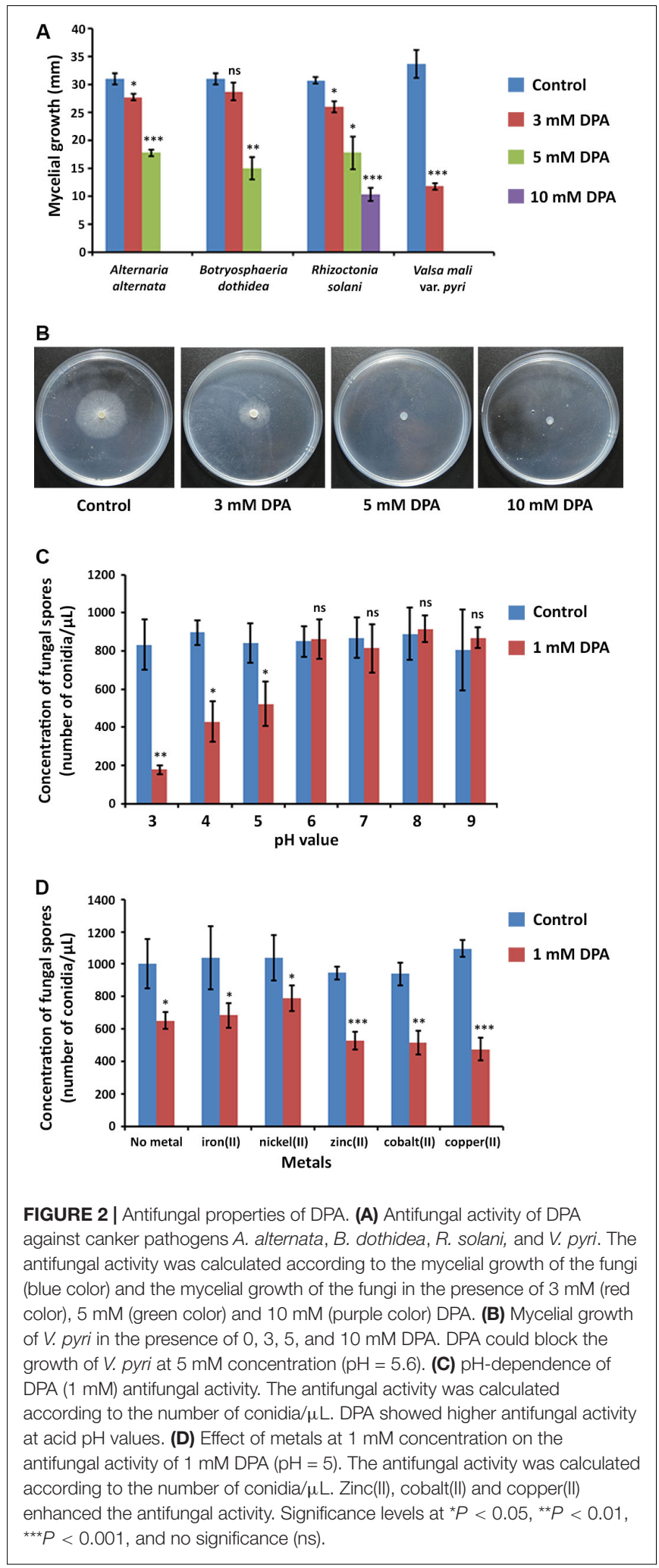

and VPSMT genes, which encode $N$-acetylglucosaminephosphate mutase, 3-hydroxy-3-methylglutaryl-CoA reductase, sterol $\mathrm{O}$-acyltransferase and $\mathrm{S}$-adenosyl-methionine-sterol-C-

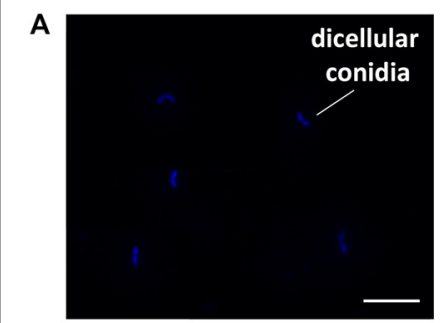

$\mathbf{O h}$

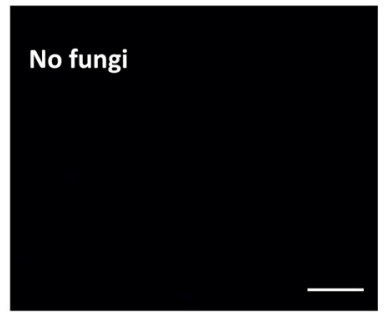

$72 \mathrm{~h}$ with $5 \mathrm{mM}$ DPA

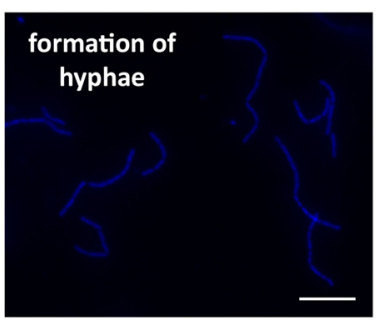

$72 \mathrm{~h}$

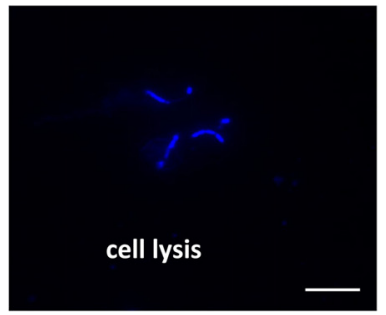

$24 \mathrm{~h}$ with $5 \mathrm{mM}$ DPA

\section{$5 \mathrm{mM}$ DPA for $24 \mathrm{~h}$}

B
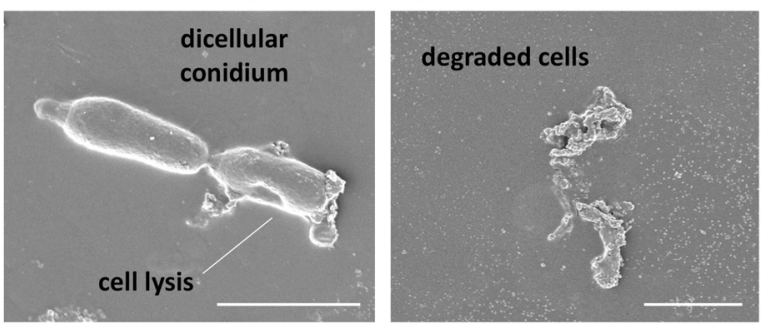

FIGURE 3 | Microscope observations of $V$. pyri cell cycle and antifungal effects of DPA. (A) Observations of DAPI-stained $V$. pyri dicellular conidia and hyphae formation using a fluorescent microscope. The treatment of $V$. pyri conidia with $5 \mathrm{mM}$ DPA $(\mathrm{pH}=5)$ caused the apoptosis of $V$. pyri. Scale bar $=10 \mu \mathrm{m}$. (B) Observations of the effects of $5 \mathrm{mM}$ DPA on $V$. pyri cell wall using scanning electron microscope (SEM). The treatment was carried out for $24 \mathrm{~h}$ at $\mathrm{pH}=5$. DPA caused the distorsion of $\mathrm{V}$. pyri cell wall, producing the cell lysis. Scale bar $=2 \mu \mathrm{m}$.

methyltransferase, respectively. Although ergosterol biosynthesis inhibitors have been demonstrated to kill fungal cells by forming pores in the plasma membrane (Sharon et al., 2009), there were no significant difference between the expression levels of the ergosterol biosynthesis genes in the treated and non-treated cells, suggesting that DPA antifungal mechanism is not related to the ergosterol biosynthesis (Supplementary Figure S6). $V p G S 1$ and VpGS2 encode $\alpha$-1,3-glucan synthases, which participate in the synthesis of the cell wall polysaccharides. It must be noted that no $\beta$-1,3-glucan synthase was identified in $V$. pyri until date. The mRNA level of VpGS1 in the treated cells was similar to that in the non-treated cells, whereas the mRNA level of VpGS2 in the treated cells was 1.79-fold higher than that in the non-treated cells, indicating that DPA is inducing the overexpression of $V p G S 2$ (Figure 4A). The chitin synthase genes VpCHS2 and VpCHS6 were 2.5- and 4.9-fold, respectively, downregulated in the treated fungi. In 


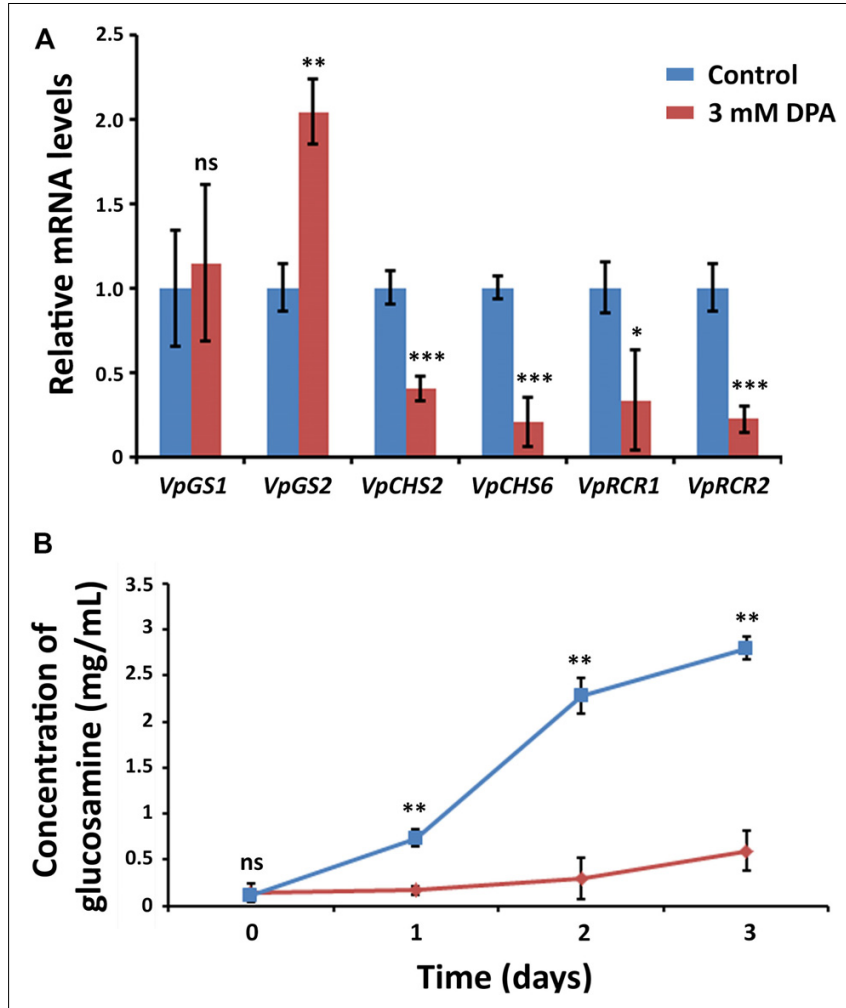

FIGURE 4 | Metabolic effects of DPA. (A) Measurement of the mRNA levels in DPA-treated V. pyri conidia. Glucan biosynthesis genes VpGS1 and VpGS2 and chitin biosynthesis genes VpCHS2, VpCHS6, VpRCR1, and VpRCR2 were examined. $V$. pyri was treated with $3 \mathrm{mM}$ DPA $(\mathrm{pH}=5)$, whereas the control experiments were performed in the absence of DPA. The obtained results indicated that DPA is inhibiting the biosynthesis of chitin.

(B) Determination of chitin concentration in $V$. pyri after treatment with $3 \mathrm{mM}$ DPA at $\mathrm{pH}=5$. The control experiment was carried out in the absence of DPA. The concentration of chitin was lower in the DPA-treated fungi in comparison to that in the non-treated fungi, demonstrating that DPA is inhibiting the biosynthesis of chitin. Significance levels at ${ }^{*} P<0.05$, ${ }^{\star \star} P<0.01,{ }^{* \star \star} P<0.001$, and no significance (ns).

agreement with this result, the expression levels of $V p R C R 1$ and $V P R C R 2$, which are responsible for the deposition of chitin on the cell wall, were 3 and 4.5 times lower in the treated cells than those in the non-treated cells (Figure 4A). These results suggest that DPA is inhibiting the biosynthesis of chitin in $V$. pyri. Although our research group reported that transcription factor $V p C R Z 1$ is involved in the regulation of chitin biosynthesis (He et al., 2016), no significant difference was observed in the mRNA level of VpCRZ1 in the DPA-treated cells, indicating that DPA is inhibiting chitin biosynthesis in a $V p C R Z 1$-independent manner. In order to confirm that DPA is inhibiting chitin biosynthesis, the concentration of chitin in the DPA-treated cells was measured at 0, 1, 2, and 3 days (Figure 4B). In agreement with the mRNA levels, the concentration of chitin in the fungi only slightly increased in the presence of $3 \mathrm{mM}$ DPA. In contrast, the concentration of chitin in the fungi without DPA greatly increased over time, achieving the maximum after 3 days.
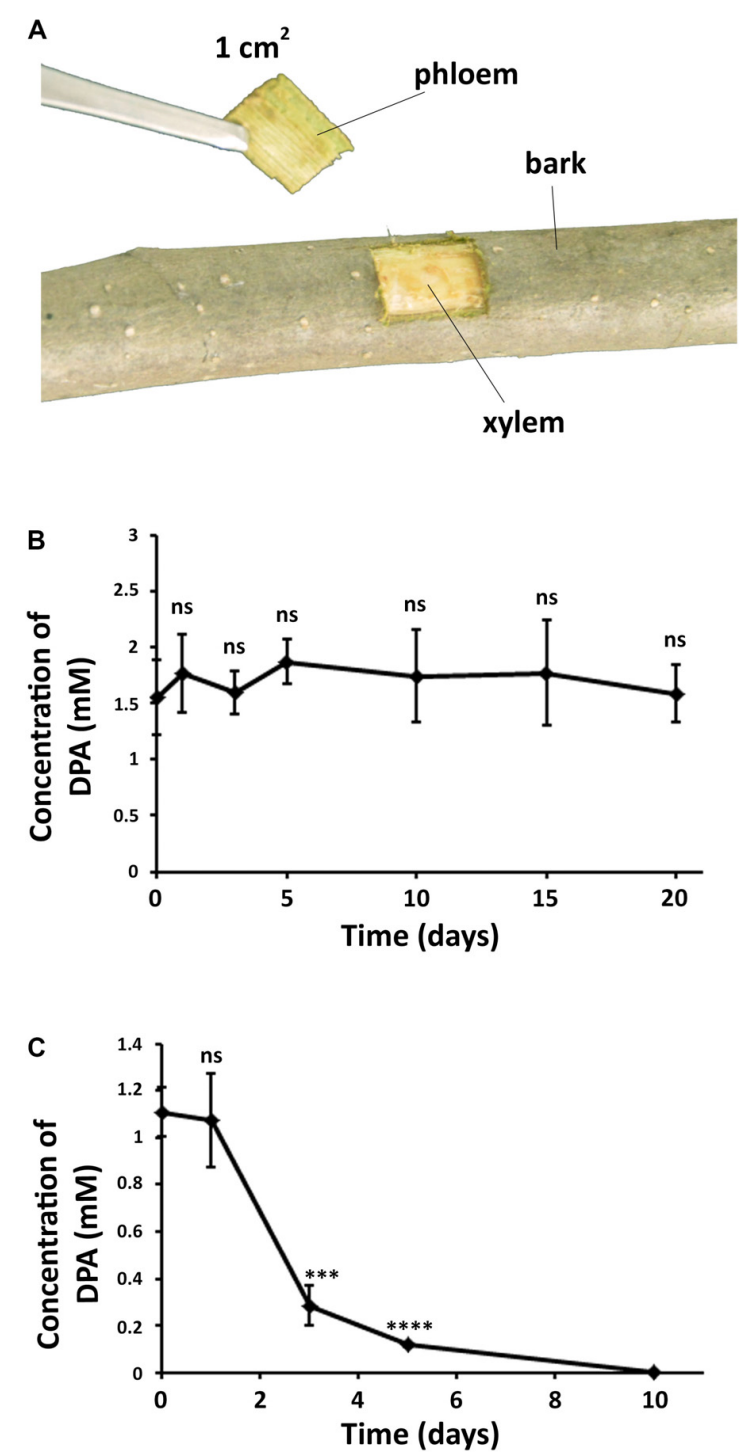

FIGURE $\mathbf{5}$ | Diffusion and stability of DPA in the pear trunk. (A) Extraction of samples from DPA-treated branches in pear trees. DPA treatment was carried out by spraying a $12 \mathrm{mM}$ DPA solution $(300 \mathrm{~mL})$ on the pear branches. (B) Concentration of DPA in pear bark over time. (C) Concentration of DPA in pear phloem over time. The obtained results indicated that DPA can cross the pear bark and shows high stability in the pear bark. Ten samples were collected for each time point. Significance levels at ${ }^{\star \star \star} P<0.001$, ${ }^{\star \star \star \star} P<0.0001$, and no significance (ns).

\section{DPA Is Able to Diffuse in the Pear Bark Into the Phloem and Inhibits the Growth of $V$. pyri in Pear Trunk}

DPA was found to be present in both bark and phloem of pear trees after the treatment (Figure 5 and Supplementary Figure S7), demonstrating that DPA is able to cross the tree bark into phloem. It must be noted that no DPA was detected in the xylem, which suggests that the diffusion of DPA into deeper trunk phases is not occurring. The concentration of DPA remained 
unaltered in the bark for 20 days, indicating that DPA shows high stability in the pear bark. However, DPA significantly degraded in the phloem at 3 days after the treatment, and no DPA could be detected after 10 days. The concentration of DPA in the phloem remained stable during the first $24 \mathrm{~h}$.

The curative and preventive abilities of DPA to reduce the symptoms of $V$. pyri in wounds of pear trunks were examined. To achieve this goal, $V$. pyri conidia was used in the inoculations. The disease advancement in the trunk was measured according the produced lesion length in 2-year Cuigan pear trees (Figure 6 and Supplementary Figure S8). Interestingly, DPA at $12 \mathrm{mM}$ concentration could reduce the lesion length by $79 \%$ in curative applications; whereas, in preventive applications, DPA reduced the lesion length by $90 \%$. Thus, the obtained results demonstrated that DPA is an efficient agent for the biocontrol of Valsa canker.

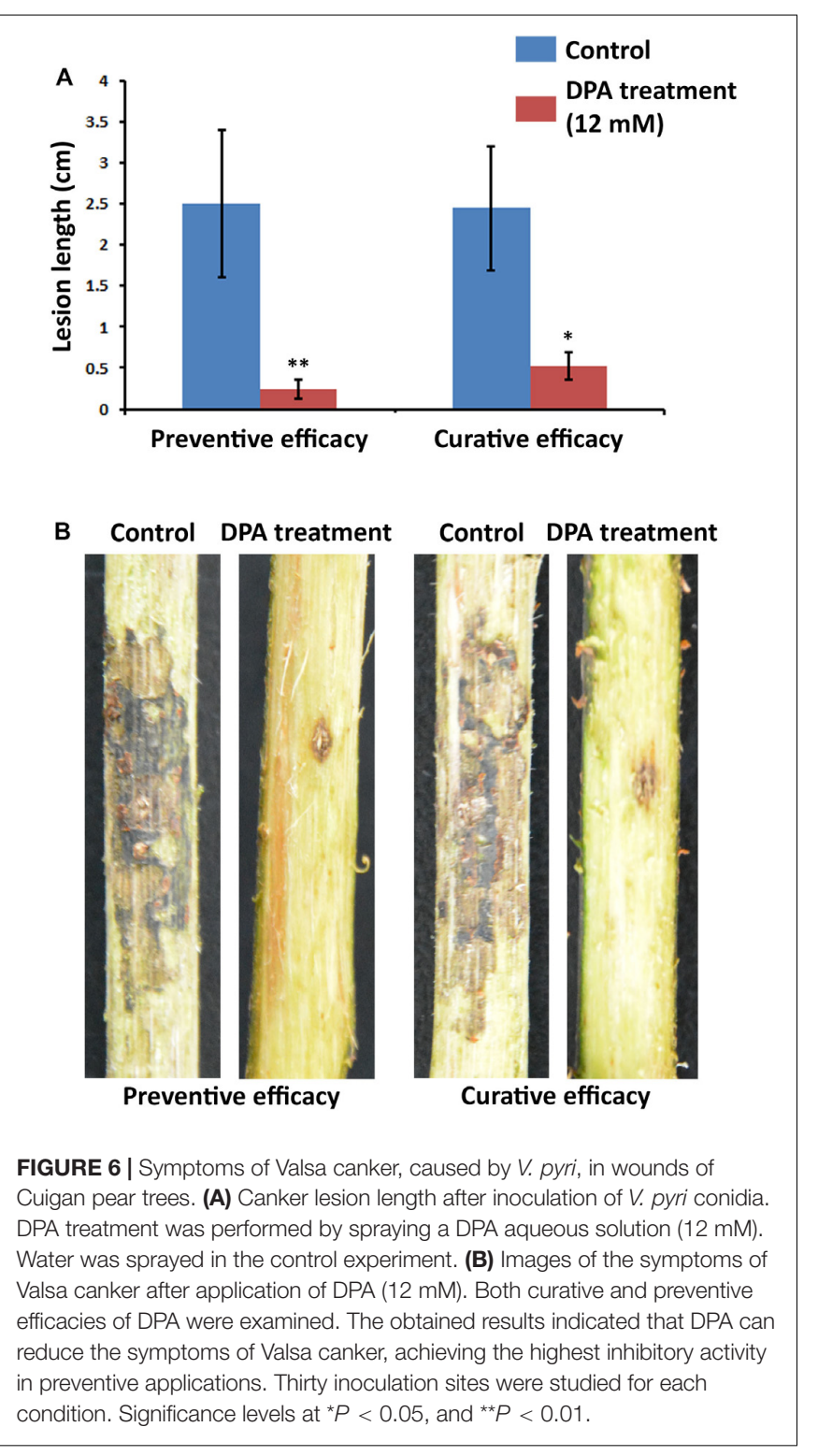

\section{DISCUSSION}

The biosynthetic pathway of DPA in B. subtilis is well known, and consists of the dihydropicolinic acid synthase-catalyzed condensation of pyruvate and L-aspartyl- $\beta$-semialdehyde to give 2,3-dihydrodipicolinic acid, which is then transformed into DPA via DPA synthetase (Chasin and Szulmajster, 1967). The DPA synthetase is encoded by the spoVF operon. DPA has been mainly related to the formation of Bacillus spores since DPA composes from 5 to $15 \%$ of the dry weight of the spores (Rao et al., 2016; Barak, 2017). It must be remarked that, although DPA is a common metabolite in $B$. subtilis strains, the antifungal activity of DPA was not reported in previous studies.

Although the detected concentration of DPA in wild-type B. subtilis 168 secretions $(0.24 \mathrm{mM})$ was lower than the minimal inhibitory concentration $(5 \mathrm{mM})$, previous reports have demonstrated that recombinant $B$. subtilis 168 strains can produce high amounts of DPA $(>5 \mathrm{mM})$, indicating that B. subtilis 168 is an interesting tool for DPA production. In this sense, the replacement of the spoVFA promoter with another highly expressed promoter, spoVG, in B. subtilis vegetative cells, together with improving the medium composition, increased DPA production up to $170 \mathrm{mM}$ (Takahashi et al., 2015). Toya et al. (2015) reported that the replacement of the spoVFA promoter and simultaneous deletion of acetoin synthesis genes (alsSD) led to $30 \mathrm{mM} \mathrm{DPA}$ after $40 \mathrm{~h}$ of fermentation in synthetic medium. In contrast with our results, Takahashi et al. (2015) indicated that DPA was not detected in the culture medium when using wild-type B. subtilis 168. Although the detection limit of the analysis method was not described, the lowest DPA concentration reported in that article was $1.26 \mathrm{mM}$ when using recombinant strains. Here, DPA was found at lower concentrations using wildtype B. subtilis 168 , indicating that the wild-type bacteria is also able to produce small amounts of DPA when using standard fermentation conditions.

DPA showed strong antifungal activity against hazardous canker pathogens, including A. alternata, B. dothidea, R. solani, and $V$. pyri. A. alternata was reported to cause stem canker in tomato plants, whereas potato stem canker is caused by R. solani (Tsror, 2010; Shao et al., 2019). B. dothidea and $V$. pyri are able to produce canker disease in apple and pear trees (Zhai et al., 2014; Yin et al., 2015). The obtained results indicated that DPA is producing $V$. pyri apoptosis via inhibition of chitin biosynthesis. In filamentous fungi (such as V. pyri), chitin comprises up to $15 \%$ of the cell wall mass. Chitin is connected by covalent and ion bonds to other polysaccharides, pigments and proteins, conferring rigidity. As observed in DPAtreated $V$. pyri, low chitin concentrations have been reported to induce osmotic cell lysis in different fungal species, such as S. cerevisiae or Aspergillus nidulans (Takeshita et al., 2006; Luu et al., 2019). Several antifungal agents are known to block fungal growth via inhibition of chitin biosynthesis, and this fact has been used to combat fungal pathogens in agriculture and forestry (Merzendorfer, 2013). For example, chitin biosynthesis inhibitor polyoxin D is commercially available and has been extensively used for the management of rice sheath blight in Japan (Merzendorfer, 2013). Cyclopentene-1,3-dione was identified in 
Acca sellowiana and was shown to inhibit chitin biosynthesis in Candida spp. (Mokhtari et al., 2018). Phenazine-1-carboximade inhibited the mycelial growth of $R$. solani by inhibiting the activity of the chitin synthases (Yu et al., 2018).

The inhibition of the $\beta$-1,3-glucan synthases in A. infectoria using caspofungin resulted in the upregulation of the chitin synthases as a compensatory effect (Fernandes et al., 2014). The compensatory effect between chitin and glucan synthases was also observed in Candida albicans and Aspergillus fumigatus (Fortwendel et al., 2009). The obtained results indicated that DPA is inducing the upregulation of VpGS2 and, at the same time, the downregulation of chitin synthases and chitin deposition genes. The upregulation of VpGS2 must be produced in V. pyri as a compensatory effect of chitin biosynthesis inhibition.

Our research group has recently reported the sorption of antifungal $p$-aminobenzoic acid (pABA) into the internal phases of pear fruits (Laborda et al., 2018, 2019). In that work, pABA inhibited the symptoms of Colletotrichum fructicola, and started to degrade in the pear skin and mesocarp at 5 days after the treatment. The diffusion ability of some organic compounds in fruits has been related to their low molecular weight (Baur and Schönherr, 1995). Similarly, some organic toxins, such as trichloroethylene $(\mathrm{MW}=131.40)$, tetrachloroethylene $(\mathrm{MW}=165.83)$, pyrene $(\mathrm{MW}=202.25)$, and hexachlorobenzene $(\mathrm{MW}=284.80)$, can be absorbed by pear barks, and this ability has been also related to their low MW (Li et al., 2005, 2010; Gopalakrishnan et al., 2009). As mentioned in the introduction section, $V$. pyri invades the pear phloem and, for this reason, $V$. pyri canker is difficult to control with chemical agents. Here, we explored the diffusion ability of antifungal DPA, which shows a low molecular weight $(\mathrm{MW}=167.02)$, in the trunk of pear trees, demonstrating that DPA can be absorbed by both pear bark and, interestingly, phloem. Previous reports indicated that fungicides with half lifes $\left(\mathrm{T}_{1 / 2}\right)$ of 5-7 days are suitable to control pear and apple diseases (Bhat et al., 2015). Our results indicated that DPA was stable in the pear bark for more than 20 days, which demonstrates that DPA is a suitable antifungal agent for the management of trunk diseases. Although DPA was shown to be less stable as in the phloem than in the bark, no degradation could be detected during the first $24 \mathrm{~h}$. As previously indicated, DPA was able to cause the death of $V$. pyri in only $24 \mathrm{~h}$, which suggests

\section{REFERENCES}

Abdolmaleki, S., Ghadermazi, M., Ashengroph, M., Saffari, A., and Sabzkohi, S. M. (2018). Cobalt(II), zirconium(IV), calcium(II) complexes with dipicolinic acid and imidazole derivatives: X-ray studies, thermal analyses, evaluation as in vitro antibacterial and cytotoxic agents. Inorganica Chim. Acta 480, 70-82. doi: 10.1016/j.ica.2018. 04.047

Barak, I. (2017). Editorial: spores and spore formers. Front. Microbiol. 8:1046. doi: $10.3389 /$ fmicb.2017.01046

Baur, P., and Schönherr, J. (1995). Temperature dependence of the diffusion of organic compounds across plant cuticles. Chemosphere 30, 1331-1340. doi: 10.1016/0045-6535(95)00033-5

Bhat, M., Wani, A. A., Mukhtar, M., Sherwani, A., Bhat, A. H., and Showkat, A. (2015). Dissipation patterns of fungicide difenoconazole (25\% EC) in apples grown in Kashmir, India. Environ. Monit. Assess. 187:398. doi: 10.1007/s10661015-4625-0 that this dissipation time must be enough to control Valsa canker. As far as we know, this is the first time that the diffusion ability of an antifungal agent is studied in tree trunks.

In agreement with the observed antifungal properties and diffusion ability, DPA reduced the symptoms of $V$. pyri in pear trees, obtaining the highest inhibitory activity in preventive applications. The developed strategy supposes one of the first efficient chemical methodologies for the management of Valsa canker.

\section{DATA AVAILABILITY STATEMENT}

The datasets supporting the conclusions of this article are included within the article and its additional files.

\section{AUTHOR CONTRIBUTIONS}

PL, X-CS, and F-QL designed the experiments. X-GS, M-HH, DL, Z-GH, and S-YW performed the experiments. FH, C-HL, and G-CW analyzed the data. PL and X-CS drafted the manuscript. All authors read and approved the final manuscript.

\section{FUNDING}

This study was supported by the National Natural Science Foundation of China (31850410485 and 81803407), the Nantong Applied Research Program (MS12017023-8), the Natural Science Research Project of Jiangsu Higher Education Institutions (18KJB180023), the China Postdoctoral Science Foundation (2018M642240), and the State Scholarship Fund of China Scholarship Council (No. 201808320100).

\section{SUPPLEMENTARY MATERIAL}

The Supplementary Material for this article can be found online at: https://www.frontiersin.org/articles/10.3389/fmicb. 2020.00958/full\#supplementary-material

Caulier, S., Nannan, C., Gillis, A., Licciardi, F., Bragard, C., and Mahillon, J. (2019). Overview of the antimicrobial compounds produced by members of the Bacillus subtilis group. Front. Microbiol. 10:302. doi: 10.3389/fmicb.2019.00302

Chasin, L. A., and Szulmajster, J. (1967). Biosynthesis of dipicolinic acid in Bacillus subtilis. Biochem. Biophys. Res. Commun. 29, 648-654. doi: 10.1016/0006291X(67)90265-3

Chen, C., Li, B. H., Dong, X. L., Wang, C. X., Lian, S., and Liang, W. X. (2016). Effects of temperature, humidity, and wound age on Valsa mali infection of apple shoot pruning wounds. Plant Dis. 100, 2394-2401. doi: 10.1094/pdis-0516-0625-re

Cheng, C., Zhao, Y., Li, H., He, F., Cao, S., Yang, X., et al. (2017). Control effect of HSAF from Lysobacter enzymogenes OH11 on pear Valsa canker. Zhongguo Sheng Wu Fang Zhi 33, 114-120. doi: 10.16409/j.cnki.2095-039x.2017.01.016

Fernandes, C., Anjos, J., Walker, L. A., Silva, B. M. A., Cortes, L., Mota, M., et al. (2014). Modulation of alternaria infectoria cell wall chitin and glucan synthesis by cell wall synthase inhibitors. Antimicrob. Agents Chemother. 58, 2894-2904. doi: 10.1128/AAC.02647-13 
Food and Agriculture Organization of the United Nations [FAO] (2017). Available online at: http://www.fao.org/faostat/en/\#data/QC/visualize (accessed January $31,2020)$.

Fortwendel, J. R., Juvvadi, P. R., Pinchai, N., Perfect, B. Z., Alspaugh, J. A., Perfect, J. R., et al. (2009). Differential effects of inhibiting chitin and 1,3- $\beta$-D-glucan synthesis in ras and calcineurin mutants of Aspergillus fumigatus. Antimicrob. Agents Chemother. 53, 476-482. doi: 10.1128/AAC.01154-08

Gopalakrishnan, G., Burken, J. G., and Werth, C. J. (2009). Lignin and lipid impact on sorption and diffusion of trichloroethylene in tree branches for determining contaminant fate during plant sampling and phytoremediation. Environ. Sci. Technol. 43, 5732-5738. doi: 10.1021/es9006417

He, F., Zhang, X., Li, B., Safdar, A., Ai, G., Kange, A. M., et al. (2018). Comparative transcriptomics of two Valsa pyri isolates uncover different strategies for virulence and growth. Microb. Pathog. 123, 478-486. doi: 10.1016/j.micpath. 2018.08.013

He, F., Zhang, X., Mafurah, J. J., Zhang, M., Qian, G., Wang, R., et al. (2016). The transcription factor VpCRZ1 is required for fruiting body formation and pathogenicity in Valsa pyri. Microb. Pathog. 95, 101-110. doi: 10.1016/j. micpath.2016.02.018

Johnson, K. B., and Temple, T. N. (2017). Induction of systemic acquired resistance aids restoration of tree health in field-grown pear and apple diseased with fire blight. Plant Dis. 101, 1263-1268. doi: 10.1094/PDIS-12-16-1772-RE

Kange, A. M., Xia, A., Si, J., Li, B., Zhang, X., Ai, G., et al. (2020). The fungal specific transcription factor VpFSTF1 is required for virulence in Valsa pyri. Front. Microbiol. 10:2945. doi: 10.3389/fmicb.2019.02945

Kapteyn, J. C., Hoyer, L. L., Hecht, J. E., Muller, W. H., Andel, A., Verkleij, A. J., et al. (2000). The cell wall architecture of Candida albicans wild-type cells and cell wall-defective mutants. Mol. Microbiol. 35, 601-611. doi: 10.1046/j.13652958.2000.01729.x

Laborda, P., Li, C., Zhao, Y., Tang, B., Ling, J., He, F., et al. (2019). Antifungal metabolite $p$-aminobenzoic acid (pABA): mechanism of action and efficacy for the biocontrol of pear bitter rot disease. J. Agric. Food Chem. 67, 2157-2165. doi: 10.1021/acs.jafc. 8 b05618

Laborda, P., Zhao, Y., Ling, J., Hou, R., and Liu, F. (2018). Production of antifungal p-aminobenzoic acid in Lysobacter antibioticus OH13. J. Agric. Food Chem. 66, 630-636. doi: 10.1021/acs.jafc.7b05084

Li, H., Sheng, G. Y., Chiou, C. T., and Xu, O. Y. (2005). Relation of organic contaminant equilibrium sorption and kinetic uptake in plants. Environ. Sci. Technol. 39, 4864-4870. doi: 10.1021/es050424z

Li, Y. G., Chen, B. L., and Zhu, L. Z. (2010). Enhanced sorption of polycyclic aromatic hydrocarbons from aqueous solution by modified pine bark. Bioresour. Technol. 101, 7307-7313. doi: 10.1016/j.biortech.2010. 04.088

Li, Z., Yin, Z., Fan, Y., Xu, M., Kang, Z., and Huang, L. (2015). Candidate effector proteins of the necrotrophic apple Canker pathogen Valsa mali can suppress BAX-induced PCD. Front. Plant Sci. 6:579. doi: 10.3389/fpls.2015. 00579

Li, Z. P., Gao, X. N., Kang, Z. S., Huang, L. L., Fan, D. Y., Yan, X., et al. (2016). Saccharothix yanglingensis strain Hhs.015 is a promising biocontrol agent on apple Valsa canker. Plant Dis. 100, 510-514. doi: 10.1094/PDIS-02-150190-RE

Liu, C., Sheng, J. P., Chen, L., Zheng, Y. Y., Lee, D. Y. W., Yang, Y., et al. (2015). Biocontrol activity of Bacillus subtilis isolated from Agaricus bisporus mushroom compost against pathogenic fungi. J. Agric. Food Chem. 63, 60096018. doi: 10.1021/acs.jafc.5b02218

Luu, V. T., Moon, H. Y., Yoo, S. J., Choo, J. H., Thak, E. J., and Kang, H. A. (2019). Development of conditional cell lysis mutants of Saccharomyces cerevisiae as production hosts by modulating OCH1 and CHS3 expression. Appl. Microbiol. Biotechnol. 103, 2277-2293. doi: 10.1007/s00253-019-09614-4

Merzendorfer, H. (2013). Chitin synthesis inhibitors: old molecules and new developments. Insect Sci. 20, 121-138. doi: 10.1111/j.1744-7917.2012. 01535.x

Mokhtari, M., Jackson, M. D., Brown, A. S., Ackerley, D. F., Ritson, N. J., Keyzers, R. A., et al. (2018). Bioactivity-guided metabolite profiling of feijoa (Acca sellowiana) cultivars identifies 4-cyclopentene-1,3-dione as a potent antifungal inhibitor of chitin synthesis. J. Agric. Food Chem. 66, 5531-5539. doi: 10.1021/ acs.jafc.7b06154

Rao, L., Zhao, F., Wang, Y., Chen, F., Hu, X., and Liao, X. (2016). Investigating the inactivation of mechanism of Bacillus subtilis spores by high pressure $\mathrm{CO} 2$. Front. Microbiol. 7:1411. doi: 10.3389/fmicb.2016.01411
Ren, J. J., He, W. H., Li, C. Y., He, S., and Niu, D. Z. (2019). Purification and identification of a novel antifungal protein from Bacillus subtilis XB-1. World J. Microbiol. Biotechnol. 35:150. doi: 10.1007/s11274-019-2726-6

Santoyo, G., del Carmen Orozco-Mosqueda, M., and Govindappa, M. (2012). Mechanisms of biocontrol and plant growth-promoting activity in soil bacterial species of Bacillus and Pseudomonas: a review. Biocontrol Sci. Technol. 22, 855-872. doi: 10.1080/09583157.2012.694413

Shao, Z., Zhao, Y., Liu, L., Chen, S., Li, C., Meng, F., et al. (2019). Overexpression of FBR41 enhances resistance to sphinganine analog mycotoxin-induced cell death and Alternaria stem canker in tomato. Plant Biotechnol. J. 18, 141-154. doi: 10.1111/pbi.13182

Sharon, A., Finkelstein, A., Shlezinger, N., and Hatam, I. (2009). Fungal apoptosis: function, genes and gene function. FEMS Microbiol. Rev. 33, 833-854. doi: 10.1111/j.1574-6976.2009.00180.x

Siahmoshteh, F., Hamidi-Esfahani, Z., Spadaro, D., Shams-Ghahfarokhi, M., and Razzaghi-Abyaneh, M. (2018). Unraveling the mode of antifungal action of Bacillus subtilis and Bacillus amyloliquefaciens as potential biocontrol agents against aflatoxigenic Aspergillus parasiticus. Food Control 89, 300-307. doi: 10.1016/j.foodcont.2017.11.010

Takahashi, F., Sumitomo, N., Hagihara, H., and Ozaki, K. (2015). Increased dipicolinic acid production with an enhanced spoVF operon in Bacillus subtilis and medium optimization. Biosci. Biotechnol. Biochem. 79, 505-511. doi: 10. 1080/09168451.2014.978261

Takeshita, N., Yamashita, S., Ohta, A., and Horiuchi, H. (2006). Aspergillus nidulans class V and VI chitin synthases $C s m A$ and $C \operatorname{sim} B$, each with a myosin motorlike domain, perform compensatory functions that are essential for hyphal tip growth. Mol. Microbiol. 59, 1380-1394. doi: 10.1111/j.1365-2958.2006. 05030.x

Toya, Y., Hirasawa, T., Ishikawa, S., Chumsakul, O., Morimoto, T., Liu, S., et al. (2015). Enhanced dipicolinic acid production during the stationary phase in Bacillus subtilis by blocking acetoin synthesis. Biosci. Biotechnol. Biochem. 79, 2073-2080. doi: 10.1080/09168451.2015.1060843

Tsror, L. (2010). Biology, epidemiology and management of Rhizoctonia solani on potato. J. Phythopathol. 158, 649-658. doi: 10.1111/j.1439-0434.2010.01671.x

Wang, N. N., Yan, X., Gao, X. N., Niu, H. J., Kang, Z. S., and Huang, L. L. (2016). Purification and characterization of a potential antifungal protein from Bacillus subtilis E1R-J against Valsa mali. World J. Microbiol. Biotechnol. 32:63. doi: 10.1007/s11274-016-2024-5

Xu, W. F., Ren, H. S., Ou, T., Lei, T., Wei, J. H., Huang, C. S., et al. (2019). Genomic and functional characterization of the endophytic Bacillus subtilis 7PJ-16 strain, a potential biocontrol agent of mulberry fruit sclerotiniose. Microb. Ecol. 77, 651-663. doi: 10.1007/s00248-018-1247-4

Yin, Z., Liu, H., Li, Z., Ke, X., Dou, D., Gao, X., et al. (2015). Genome sequence of Valsa canker pathogens uncovers a potential adaptation of colonization of woody bark. New Phytol. 208, 1202-1216. doi: 10.1111/nph.13544

Yu, D. M., Fang, Y. L., Tang, C., Klosterman, S. J., Tian, C. M., and Wang, Y. L. (2018). Genomewide transcriptome profiles reveal how Bacillus subtilis lipopeptides inhibit microsclerotia formation in Verticillium dahliae. Mol. Plant Microbe Interact. 32, 622-634. doi: 10.1094/MPMI-08-18-0233-R

Zhai, L., Zhang, M., Lv, G., Chen, X., Jia, N., Hong, N., et al. (2014). Biological and molecular characterization of four Botryosphaeria species isolated from pear plants showing stem wart and stem canker in China. Plant Dis. 98, 716-726. doi: 10.1094/PDIS-10-13-1060-RE

Zhao, H., Wang, C., Chen, X., Wang, H., and Li, B. (2012). Methods of promoting sporulation of Valsa ceratosperma. Zhongguo Nong Xue Tong Bao 28, 151-154.

Zhou, M. S., Li, P. Z., Wu, S. Y., Zhao, P. Y., and Gao, H. Y. (2019). Bacillus subtilis CF-3 volatile organic compounds inhibit Monilinia fructicola growth in peach fruit. Front. Microbiol. 10:1804. doi: 10.3389/fmicb.2019.01804

Conflict of Interest: The authors declare that the research was conducted in the absence of any commercial or financial relationships that could be construed as a potential conflict of interest.

Copyright $\odot 2020$ Song, Han, He, Wang, Li, Wu, Huang, Liu, Liu, Laborda and Shi. This is an open-access article distributed under the terms of the Creative Commons Attribution License (CC BY). The use, distribution or reproduction in other forums is permitted, provided the original author(s) and the copyright owner(s) are credited and that the original publication in this journal is cited, in accordance with accepted academic practice. No use, distribution or reproduction is permitted which does not comply with these terms. 